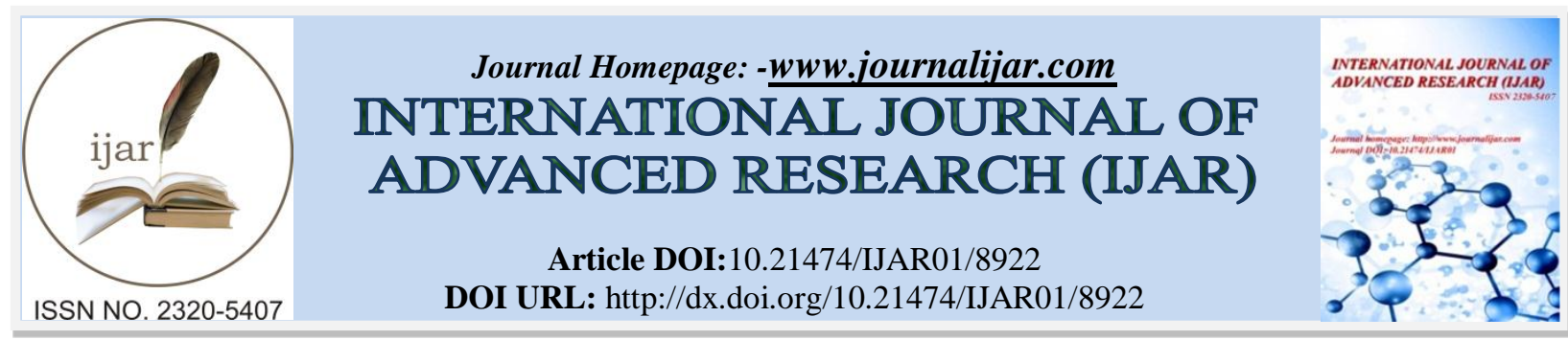

RESEARCH ARTICLE

\title{
ENFLUENCE OF SCHOOL FEEDING PROGRAMME ON PERFORMANCE OF PUBLIC PRIMARY SCHOOLS in BOSSASO DISTRICT BARI REGION, PUNTLAND - SOMALIA.
}

Issa OMar M , Prof. Willy Muturi and Prof. Mohamed Said Samantar.

Research project submitted to the department of development studies, in the school of communication and development studies, college of human resource development in partial fulfilment of the requirement for the award of the master degree at, jomo kenyatta university of agriculture and technology. Jkuat.

\section{Manuscript Info}

\section{Manuscript History}

Received: 20 February 2019

Final Accepted: 22 March 2019

Published: April 2019

Key words:-

Green's function, Fick's Law, Thermal

diffusivity, Thermal conductivity.

\section{Abstract}

According UNICEF report 2015 Somalia are amongst one of the poorest enrolment rates for primary school-aged children in the world. This mainly due to consecutive droughts, prolonged conflicts, economic collapse, mass displacement, poor government, for nearly 3 decades. To increase the enrolment rates of the primary Schools, WFP, in partnership with the Puntland Ministry of Education, initiated a school meals programme in the 2005/ 2006 scholastic year - targeting 17 schools, and reaching out to 3,473 schoolchildren. Since then, new schools joined to the School feeding programme increased on yearly bases. The main objective of the study is to investigate the effect of school feeding programme to the Bossaso Primary Schools. The main findings of the study summarized according to the results of the research and it has confirmed that in general the School Feeding Schools increased by $110 \%$ compared to the Non School Feeding, which achieved enrolment rate of $88 \%$ during the last 12 years according to the MOE data. According MOE data, the pupil's completion percentage or retention rate of the Scholastic point out those students receiving School Meals constantly shown higher compared to the Non School Meal Pupils by an average of $9 \%$. The data indicate that 11 out of 12 years the School Feeding schools enrolled higher girls by $46 \%$ compared to the Non School Feeding by $44 \%$. In terms of Academic Performance, the research investigated percentage of the School pupils promoted to the next grade in the last 12 years. According Ministry of Education data Non School Feeding Program Pupils failure were an average of 5\% during last twelve years against $2.3 \%$ of the School Feeding Pupils, which is equivalent to $97.7 \%$, promoted to the next Scholastic compared to the $95 \%$ for Control Primary Schools, which quite significant for high number of Schools Pupils to achieve required academic performance. The conclusion arising from study to obtain the relationship between School Feeding and academic performance of the Bossaso Public primary Schools proved that school meals contributed significant and 11 out of

Corresponding Author:-Issa Omar Musa.

Address: - Research project submitted to the department of development studies, in the school of 1029 communication and development studies, college of human resource development in partial fulfilment of the requirement for the award of the master degree at, jomo kenyatta university of agriculture and technology. JKUAT and Puntland state university PSU. 
12 year's school feeding pupils performed higher than nonschool feeding pupils did..

Copy Right, IJAR, 2019,. All rights reserved.

\section{Introduction:-}

Education is upheld as a fundamental human right globally and is recognized as pivotal for the attainment of self-fulfillment and national development (United Nations Educational, Scientific and Cultural Organization UNESCO, (2010)). Education is therefore, touted as the most important factor for achieving sustainable development and used as an important means for changing attitudes and behaviors.

The Hyogo framework for action (HFA), which was adopted by 168 nations in January 2005 recognize this and encourages government and civic society to use education, which facilitate knowledge and innovation, in order to build a culture of safety, and resilience at all levels of the nation Nakileza, (2007)).

As a result, governments have placed enormous resources both financial and human to enhance education in their respective countries UNESCO, (2010). Individual parents have also placed emphasis on the education of their children as the only good inheritance they can give their children.

In both developed and developing countries including Countries in Post conflict stage, school feeding programs have demonstrated a trusted ability to raise and sustain school enrollment rates, as well as combat malnutrition among low-income populations. In the context of developing countries, the promise of a meal at school can be a powerful incentive for families to send their children to school, instead of keeping them at home to work. By increasing enrollment incentives in this way, developing countries set off a powerful chain reaction: increased enrollment leads to increased literacy and education rates, which in turn leads to increased economic sustainability and opportunity. In this way, school feeding programs are a catalyst for widespread socio- and economic development. As the international community focuses its work on the achievement of the Sustainable Development Goals (SDGs) to eradicate extreme poverty, increase universal education, reduce child mortality, and promotes gender equality by 2015 , the use of school feeding programs in developing nations is clearly a critical intervention that shouldbe considered. UNESCO, (2010))

In many poor households, hunger has been a barrier to school participation. A hunger-stricken child is only unable to enrol in school at the right age but also cannot attend properly even if enrolled. Besides, such children are also likely to quit school because they have to deal with their immediate subsistence needs before they get ready for schooling Douben, (2006)).. Thus, low school enrolment, low class attendance and high student dropouts are recurring problems in child education among poor households especially in areas of high food insecurity. Due to the reasons the level of education attainment has also been low in many developing countries although both private and social returns to education are recognized to be high (Adelman, Alderman, Gilligan \& Lehrer, 2009). However, there is no doubt that other manifestations of poverty-than hunger-also affect school participation among poor households.

WFP School Feeding Program introduced in scholastic year of 2005-2006 with 17 primary schools as pilot project. WFP and Community Education Committees (CEC) funded the Programme under the supervision of Ministry of Education. The total program beneficiaries were of 3,473 Pupils from three regions of Bari, Nugaal and Mudug. The pilot project was successful and WFP and Ministry of agreed to increase in terms of Geographical coverage and number of schools under school Feeding Programme.

\section{Historical background}

\section{Nutrition is crucial in the child's physical, emotional and cognitive}

Development. Food has been acknowledged as life and a power in activating people's life as well as supporting various aspects of child development and that is depended upon correct amount and quality Omago (1990)• 
Somalia has one of the world's lowest enrolment rates for primary school-aged children. Recurrent droughts, prolonged conflicts, structural poverty, continuous displacement, lack of central government, for nearly 27 years have seriously hampered opportunity for children to enroll in, attend, and complete primary schools. Because of the civil war, educational infrastructure and support system also broke down. Most schools looted, destroyed, or converted to uses other than for the sector. Nevertheless, significant progress has made in the reconstruction of education infrastructure especially in Puntland. Significant development has also been made in terms of primary gross enrolment rate as follows: $41 \%$ in 2011-2012 (46\% for boys and 37\% for girls) and 47\% \% (52\% for boys and $42 \%$ for girls) for 20122013 (Puntland MOE CENSUS). Despite this progress made however, Puntland still has one of the world's lowest primary gross enrolment rates. There is a high dropout rate and most of the children leave school before they reach Grade 5, particularly girls. In recognition of these serious setbacks, the Puntland Ministry of Education in cooperation and partnership with WFP and other agencies, NGOs and Community Education Committees (CECs), initiated a school feeding programme in Puntland in 2006.

WFP School Feeding Programme initiated in 2005 for the scholastic year of 2005-2006 with 17 primary schools reaching 3,473 to meet the food needs of children at schools. This was increased to 42 schools in 2008 covering 16,321 schoolchildren and 164 Schools in 2015 with a total student of 58,000 pupils in which $46 \%$ girls and boys $54 \%$ approximately.

\section{Problem Statement:}

Somalia country has one of the world's poorest enrolment rates for primary school-aged children. consecutive droughts, prolonged conflicts, economic collapse, mass displacement, poor government, for nearly 3 decade have seriously hindered opportunity for children to enroll in, attend, and complete primary schools UNICEF Somalia (2015). Due civil war, educational infrastructure and support system also broke down. Nevertheless, significant progress been made in the reconstruction of education infrastructure especially in Puntland. Significant development has also been made in terms of primary gross enrolment rate as follows: $41 \%$ in 2011-2012 (46\% for boys and 37\% for girls) and $47 \%$ (52\% for boys and $42 \%$ for girls) for 2012-2013 (Puntland MOE CENSUS). Also according to the GO-2 School initiative/2013/2016 by Federal Government and UNICEF Programme indicated that out of every 10 school-aged children in Somalia only 4 of them are in school in which Puntland is part of this poor enrolment of the primary school aged children.

To reduce the impact of the above-mentioned problems, WFP, in partnership with the Puntland Ministry of Education, initiated a school meals programme in the 2005/ 6 scholastic year - targeting 17 schools, and reaching out to 3,473 schoolchildren. The targeted number of schools under the school meals programme has been steadily increasing on a yearly basis, and is currently targeting a total of 48 , 225 children in 133 schools. $42 \%$ of the schoolchildren are girls.

Although the School Feeding Programme established in 2005/20006 it influences academic performance of the Pupils is not yet clear. This is what this study intended to investigate and find out.

\section{Objectives of the study}

\section{General objective}

The general objectives of the study is to investigate the influence of the School Feeding Programme on the performance of Public Primary Schools in Bossaso district, Bari region Puntland -Somalia

\section{Specific objectives}

To assess the effect of school feeding programme on enrolment rate Primary Schools of in Bossaso district

To investigate the effect of school feeding programme on public primary school pupils academic performance in Bossaso District.

To determine effect of school feeding programme on retention rate of the primary school in Bossaso District. 
To determine the effect of school feeding programme on gender parity on primary school pupils in Bossaso district.

\section{Research questions}

Following are the research questions

What is the effect of school feeding program on enrolment rate on Primary School in Bossaso?

How does the school-feeding programme influence on academic performance in primary schools in Bossaso District?

How does the school feeding programme influence the retention rate of pupils in primary school in Bossaso Primary Schools?

How does the school feeding programme influence on gender parity of pupils in primary school in Bossaso.

\section{Significance of the study}

The findings from the study could be used by policy makers in the education sector of Puntland and Somalia Generally when formulating policies on the pupil's participation in schools such as construction of boarding schools and improving the school feeding programme in the region which could enhance the achievement of intended educational objectives. The study could be of importance to the communities living in the food insecure areas as it could highlight how the pupils could remain in school despite the challenges and difficulties posed by poverty and conflicts. The government, non-governmental organizations and donors could also use the findings in the identification and elevation of the factors influencing participation of pupils in public primary education in Bossaso District of Puntland, Somalia. The study could therefore become a base for further research on the area of pupil's participation in enhancing curriculum implementation. School communities can also find strategies they could undertake to ensure more students benefit from basic education programme hence empowering the local communities to come out of the cycle of poverty

\section{Scope of Study}

The study is based on the findings of the seven Bossaso primary schools of total population of 3812 primary school pupils. The study was carried out in the Puntland Bossaso district of Bari region and involve information sourced both from the school and the Ministry of Education's School Feeding Unit.

\section{Limitations of study}

Because of small sample, size and geographical area can be a limitation and the results from the study cannot be generalized results. However, the study findings offer some insights into the multifaceted nature of enrolment and retention problem in Bossaso district of Bari region, Somalia2.1 Introduction

School feeding programs are common in both developing and industrialized countries. The objectives of school feeding programs are to provide meals or snacks to reduce short-term hunger in the classroom so that the students can concentrate and learn better, and to attract children to school and have them attend regularly.

In Puntland, feeding children in school is a recent phenomenon introduced in July 200, In order to diminish hunger in the classroom as well as to promote school enrollment and retention rates, the Government of Puntland and the World Food Programme (WFP) launched the School Feeding Program (SFP) in chronically food insecure areas of Puntland.

In an effort to increase primary school enrollment of children from poor families, This school feeding program aim to increase the enrollment and retention rates of students in primary schools throughout rural and urban areas in Puntland. However, academic achievement is disappointing, especially in primary schools. Hunger is a likely reason. Widespread of undernutrition in Puntland remains a critical barrier to children is learning including micronutrients. The newly introduced school feeding program has the potential to improve children's learning performance.

1. Does the SFP increase school enrollment and attendance?

2. What are the effects on food consumption and nutrition of participating children? 
3. Has the program made any impact on children's learning?

The United Nations University commissioned the International Food Policy Research Institute (IFPRI) to conduct an evaluation of the school feeding program to answer these questions.

The information generated through this evaluation would strengthen the empirical basis on which Somalia and WFP can make informed policy choices to refine the school feeding program in order to realize the greatest benefits of education investments.

This paper report on the findings drawn from surveys undertaken in Puntland to gather information on the effects and outcomes of the school feeding program from target schools of Bossaso district of Bare region

\section{Theoretical Review}

Classroom learning is a multiplicative, diminishing-returns function of four essential factors-student ability and motivation, and quality and quantity of instruction-and possibly four supplementary or supportive factors - the social psychological environment of the classroom, education-stimulating conditions in the home and peer group, and exposure to mass media. Each of the essential factors appears to be necessary but insufficient by itself for classroom learning; that is, all four of these factors appear required at least at minimum level. It also appears that the essential factors may substitute, compensate, or tradeoff for one another in diminishing rates of return: for example, immense quantities of time may be required for a moderate amount of learning to occur if motivation, ability, or quality of instruction is minimal Haertel et al., (1983). An important finding of the Walberg et al. large scale causal modeling research was that nine different educational productivity factors were hypothesized to operate vis- à-vis a complex set of interactions to account for school learning. Additionally, some student characteristic variables (motivation, prior achievement, attitudes) had indirect effects (e.g., the influence of the variable "went through" or was mediated via another variable).

The importance of the Walberg et al. group's findings cannot be overstated. Walberg's (1981) (theory of educational productivity is one of the few empirically tested theories of school learning and is based on the review and integration of over 3,000 studies) DiPerna et al., (2002)). Walberg et al. have identified key variables that effect student outcomes: student ability/prior achievement, motivation, age/developmental level, quantity of instruction, quality of instruction, classroom climate, home environment, peer group, and exposure to mass media outside of school Walberg, Fraser \& Welch, (1986). In the current context, the first three variables (ability, motivation, and age) reflect characteristics of the student. The fourth and fifth variables reflect instruction (quantity and quality), and the final four variables (classroom climate, home environment, peer group, and exposure to media) represent aspects of the psychological environment DiPerna et al., (2002). Clearly, student characteristics are important for school learning, but they only comprise a portion of the learning equation group Powell et al. (1998).

\subsubsection{Academic Performance Theory}

More recently, Zins, Weissberg, Wang and Walberg, (2004) demonstrated the importance of the domains of motivational orientations, self-regulated learning strategies, and social/interpersonal abilities in facilitating academic performance. Zins et al. reported, based on the large-scale implementation of a Social-Emotional Learning (SEL) program, those students who became more self-aware and confident regarding their learning abilities, who were more motivated, who set learning goals, and who organized in their approach to work (self- regulated learning) performed better in school. According to Greenberg, Weissberg, O'Brien, Zins, Fredericks, Resnick, \& Elias, (2003), Zins et al. (2004) assert, "research linking social, emotional, and academic factors are sufficiently strong to advance the new term social, emotional, and academic learning (SEAL). A central challenge for researchers, educators, and policymakers is to strengthen this connection through coordinated multiyear programming"(p. 470).

Walberg and associates' conclusions resonate with findings from other fields. For example, the "resilience" literature Garmezy, (1993) grew from the observation that despite living in disadvantaged and risky environments, certain children overcame and attained high levels of achievement, motivation, 
and performance Gutman, Sameroff \& Eccles, (2002). Wachs (2000) review of biological, social, and psychological factors suggested that no single factor could explain "how" and "why" these resilient children had been inoculated from the deleterious effects of their day- to-day environments. A variety of promotive (direct) and protective (interactive) variables were suggested, which included, aside from cognitive abilities, such conative characteristics as study habits, social abilities, and the absence of behavior problems Guttman et al., (2003).

\subsubsection{Gender Parity Theory}

In the model of social-cultural perspective, reality is formed by a social consensus and is based on social interaction. For the knowledge to be truthful, it must match the social consensus and be functional Bandura, (1977) school learning and female academic performance is built on what the community knows based on their cultural expectations of women. This theory will help to explain how gender gap occurs in education. The perception of teachers, students, parents and religious leaders on the issues of the cultural values of smart girls; and the general perception of community expectations of girls lead to female performance or underperformance.

Theories of Gender Inequality Parsons, also a Functionalist, gave what is essentially a biological reason, namely that women are best at such tasks as socialization because they give birth and are thus "naturally" suited to look after children. In Psychology, in the 1950's, Bowlby argued for "maternal deprivation". Stay with you young children or else they would become criminals. So they we are. History, Biology and Psychology concluded that women should do the housework and childcare.

Although this is more in general and tend to feminist ideas in 19 century but still can valid to urge to those believe extreme ideas of gender role and responsibilities and establishing barrier women to be part of the developing world and play economic and leadership in their society. To realize these goals school feeding can be one of the tools enhancing girl's education to build strength and capabilities to face future challenges.

\subsubsection{Retention Rate Theory}

Vincent Tinto's work has paved the way for a sociological analysis of retention (e.g., 1975, 1987, and 1993), which has been popular for several decades. His research and that of his followers may credited with expanding the debate on the causes of attrition by calling attention to institutional factors that affect retention, namely the importance of academic and social integration in lessening dropout rates. Initially building on Emile Durkheim's (1951) treatise on the social roots of social deviation and William Spady (1971). Application of anomie theory (i.e., the effect of relative normlessness on human behavior) to explain dropping out, Tinto's model focuses largely on academic integration (i.e., sharing academic values) and social integration (i.e., developing student and faculty friendships) to account for variations in attribution rates. However, in subsequent renditions of his theory, he places more emphasis on the interaction between individual and institutional factors and adds other theoretical perspectives, such as Van Gennep (1960) rites of passage theory, suggesting that integration may facilitate by successful separation from family and high school associates.

Eaton J. B. and Shevawn (2000) offer an integrated multi-level model of causes of dropping out. Their model combines individual characteristics and background variables. Examples include high school experiences; students' intentions or educational goals; family Support; indicators of students' academic standing and social integration in college; how Students interact with the institutional bureaucratic structures; external factors (i.e., financial Situation or personal relationships outside of college); and ultimately students' attitudes toward themselves and the school, including feelings of fit and loyalty to the institution. The model brings together attitude-behavior theory, self-efficacy theory, coping-behavior theory, organizational turnover theory, and social integration and alienation theory.

The Sheffield School Food Project aimed to develop understanding of the social and institutional context of food practices in primary school settings in England. It also aimed to explore the factors influencing the capabilities of primary-aged pupils, parents and staff in relation to school-based eating contexts, policies and practices. The research paradigm remained open with regard to the debates raised in the introduction around the degrees of autonomy and conformity that might be encouraged among pupils regarding food practices. This is due to overriding concerns with Amartya Sen's notion of capability, 
which at times might necessitate pupil conformity whilst at others may require varying degrees of pupil autonomy. The principal goals of the research were to inform the development of pupil well-being and the social quality of school communities. The work is based on the premise that the conditions which might favor pupil well-being and school development are dynamic and can be enhanced or constrained through individual dispositions, knowledge and skills, social action and environmental settings. Yin (2003)

There are numerous theories on education performance, majority of these theories are much generalized and not specifically contributing to the school feeding sector. This could be one of the challenges of the study. However, they all aimed to explore the factors influencing the capabilities of primary-aged pupils, parents and staff in relation to school-based eating contexts, policies and practices

2.3 Conceptual Framework

School feeding is a tool, which today effectively enables hundreds of millions of poor children worldwide to attend school in developed and developing countries alike.

One of the advantages of school feeding is that, in addition to enabling education, it has positive direct and indirect benefits relating to a number of other development goals (namely for gender equity, poverty and hunger reduction, partnerships and cooperation, HIV/AIDS care and prevention, and improvements in health (Worm treatment) and other social indicators).

The term school feeding used over the years to mean the provision of meals or snacks at school to reduce children's hunger during the school day.

Some continue to define school feeding as in-school meals only. For most, however, school feeding has increasingly come to represent a more varied and comprehensive set of uses of food for the achievement of educational outcomes. School feeding and take-home rations have consistently proven effective in improving enrolment and attendance, and in reducing dropout rates among school-age children WFP (2004). This Conceptual framework is based on the idea that school-feeding program plays a crucial role on school outcomes.

There have been number of schoolers who chosen School, Feeding as independent variable to investigate its influence on various dependent variable such enrolment, attendance, academic achievement. One of these Scholars was Wekesa Kevina (2015), she emphasized her research how School Feeding as independent variable influence several outcome indicators and revealed strong linkage between School Feeding Program as independent variable and dependent variables of enrolment, attendance and Academic performance.

The other research articles who selected School Feeding program, as independent variable was DANIEL OTIENO (2014). In his study, he conducted deep investigation on how School Feeding Program influenced other outcome indicators or dependent variables including Impact on School Feeding on children attendance, learning, and quality and quantity of Academic achievements for pre-school children in Keyole Zone, Nairobi.

2.3 The conceptual framework Independent variable (IV)

Dependent variable (DV)
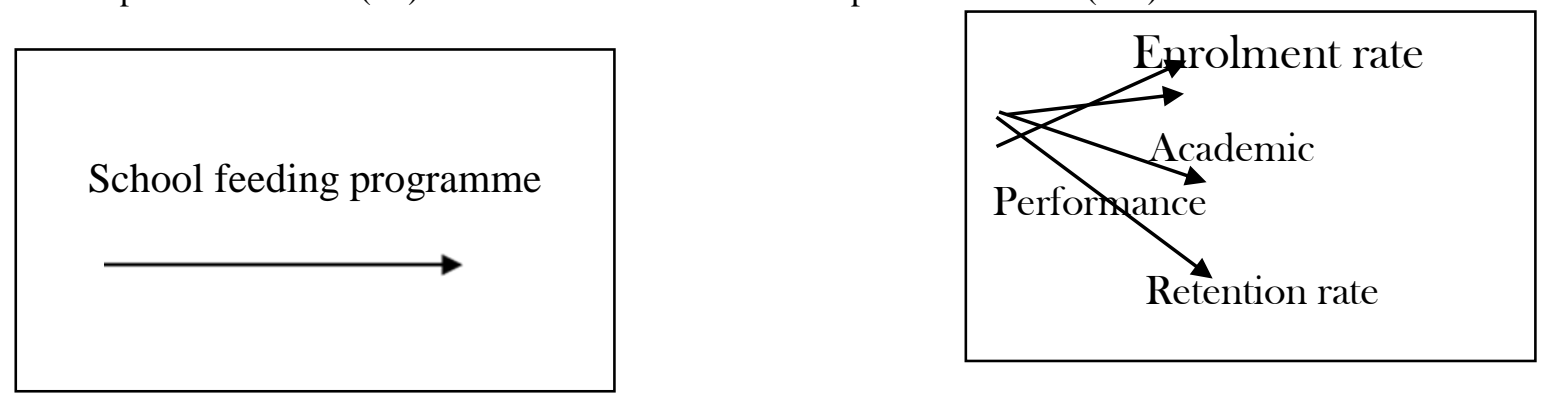

Figure 2.1:-Conceptual framework 


\section{Review of the Variables}

This study is based on the concept that the school feeding programme would help retain pupils in school through increased enrolment, attending school regularly, participating in class and hence lowering the dropout rate. The school feeding programme is the independent variable while enrolment rate, Retention rate, Academic performance and gender parity are dependent variables, School feeding programme as it acts as a strong motivating factor to the suffering children who otherwise would not have food and may therefore abandon going to school altogether will influence the pupilse participation. Therefore, the incentive of SFP on education will lead to increased pupil enrolment, regular attendance, and active participation in classroom. The framework illustrates that participation of pupils in school results from the motivating factor (SFP) and the pupil's interest and expectation of acquiring reward (good meal and education to be successful in future). It will result in participation of pupils in the learning process in school.

There have been number of schoolers who chosen School, Feeding as independent variable to investigate its influence on various dependent variable such enrolment, attendance, academic achievement. One of these Scholars was Wekesa Kevina ( 2015, She emphasized her research how School Feeding as independent variable influence several outcome indicators and revealed strong linkage between School Feeding Program as independent variable and dependent variables of enrolment, attendance and Academic performance.

The other researcher articles who selected School Feeding program, as independent variable was DANIEL OTIENO (2014). In his study, he conducted deep investigation on how School Feeding Program influenced as other outcome indicators or dependent variables including Impact on School Feeding on children attendance, learning, and quality and quantity of Academic achievements for preschool children in Keyole Zone, Nairobi.

\section{Empirical Review of the School Feeding)}

Various researchers have done this type of Research including World Food Programme, which is the largest funding agency of School Feeding globally.

Majority of the researchers have their own Hypothesis, research questions related topics and which varied from one to another. This research will focus on whether School Feeding has a positive impact on pupil's enrolment, retention and dropouts

Practically, School Feeding Programme aimed to provide school meals to the pupils at school premises. According to the experiences, school feeding worked effectively for low and middle-income countries and most common achievements include addressing Long-term correction of nutritional deficiencies for school-aged pupils enrolled under school feeding programme through provision of basic nutrition supplementary, which may not be accessed children from poor communities. This may result breaking cycle of the chronic malnutrition. School feeing programme address Short-term hunger relief at the school time. This type of hunger associate closely socio-economic standard of the family, which may counteracts the negative effect of hunger on concentration, memory, motivation, and other psychological prerequisites for learning (Trisha Greenhalgh and Elizabeth Kristjansson). School Feeding Programme also act as moral support of the pupils because children feel valued and cared by the government or education intuitions and thus could minimize dropouts and encourage acquiring of the primary education which main goal of the basic education.

\section{Enrolment:}

As bridge and Veugelers (2008:24) in support of the above, quote a study, which found that school feeding led to improved achievement in English and, when combined with a programme to develop parent-teacher partnerships improved achievement in mathematics. When cognitive development improved due to high enrolment and attendance because of a school-feeding programme, learners become constructive and contributing future citizens who are not bound by social ills such as diseases, unemployment and poverty. This implies that they are set free to achieve their fullest potential in life, which benefits them as individuals and their society 
As a whole. Finally, the provision of food at school provides the basis for bridging the gap between the enrolment of boys and girls at school World Food Programme, (2005). This results also in the empowerment of the girl-children when they have been marginalized, leading to the attainment of their freedom and being able to break away from the poverty trap. Moreover, education, especially girls' education, has a direct and proven impact on the goals related to child and reproductive health and environmental sustainability Bastia, (2007).

\section{Gender parity:}

According to an Evaluation Report on India's Mid-Day Meals Programme prepared by Dreze and Kingdon (2001) assessing the impact of school feeding on girls' enrollment and retention in primary school, the result was that girls in the programme were 30\% more likely to complete primary school than their counterparts who did not have the same advantage. In neighboring Pakistan, a WFP programme that provides a conditional THR of oil once a month, has recorded a change in attitude of parents towards education of girls. Prior to the introduction of the programme, " 48 percent of households did not send any of their daughters to school; afterwards, all households educated at least one daughter" WFP, (2005). And according to another WFP report prepared by Gelli, Meir and Espejo ( 2007) an even greater impact on girls' enrollment and retention in school via progress from grade to grade can be realized when THR are combined with school feeding while they are at school. And, in a school feeding programme in Bangladesh, enrolment of girls was increased by 44 percent while that of boys was increased by 28 percent; schools that did not have a school feeding programme only recorded an increase of 2.5 percent in their enrolment during the same time-period Ahmed, (2004).

School feeding is sustainable when key drivers are in place. Over the past 45 years, WFP has handed over school feeding programme to 31 countries where it has worked; these countries still have school feeding programme offered at some level. The most recent countries where WFP phased out school feeding were Peru and Azerbaijan during (2007-2008)

\subsubsection{Retention Rate:}

According to an Evaluation Report on India's Mid-Day Meals Programme prepared by Dreze and Kingdon (2001) assessing the impact of school feeding on girls' enrollment and retention in primary school, the result was that girls in the programme were $30 \%$ more likely to complete primary school than their counterparts who did not have the same advantage. In neighboring Pakistan, a WFP programme that provides a conditional THR of oil once a month, has recorded a change in attitude of parents towards education of girls. Prior to the introduction of the programme, "48 percent of households did not send any of their daughters to school; afterwards, all households educated at least one daughter" (WFP, 2005b). And according to another WFP report prepared by Gelli, Meir and Espejo in 2007, an even greater impact on girls' enrollment and retention in school via progress from grade to grade can be realized when THR are combined with school feeding while they are at school. And, in a school feeding programme in Bangladesh, enrolment of girls was increased by 44 percent while that of boys was increased by 28 percent; schools that did not have a school feeding programme only recorded an increase of 2.5 percent in their enrolment during the same time-period Ahmed, (2004).

UNICEF reported in 2002 that $60 \%$ of the 100 million out-of-school children in the world are girls. World Food Program studies of take-home ration programs, which reward the families of girls who enroll and attend, school regularly (usually a minimum of 22 days per month). This shows dramatic results: In one province in Pakistan, girls enrolment increased by $247 \%$ between the time the program began in 1994 and 1998, in another province, the increase was 197\% In the Extreme North province of Cameroon, the program succeeded in increasing girls' enrolment by $313 \%$.

\subsubsection{Academic Performance:}

The potential impact goal of targeting children through Food for Education programs is to increase their educational achievement to improve their potential future productivity and earnings. However, improvement in educational achievement due to serving food in SFPs thought to occur through three pathways, as demonstrated in Figure 1. First, FFE programs increase school attendance by lowering the opportunity costs of attending school and providing additional incentives to engage in formal education. This leads to more time spent in school and more time spent towards learning. The second is through the 
alleviation of short-term hunger, which improves children's cognitive functioning and attention span. The third path is through the improved nutritional status of children by providing them calories and nutrients in addition to their regular diet. This leads to better health and better resistance to infectious diseases and illnesses that would keep children from attending school Buttenheim et al. (2011). Thus, better nutrition indirectly improves educational achievement by increasing school attendance by children.

\subsection{Summary of the literature review}

Several related researches carried out with various academics and researchers with varied context and different reports prepared by UN agencies and International Organizations. The gap that was revealed was based how school feeding positively impact on enrolments, decrease dropouts and reduce gender disparity amongst other things. For instance, enrollment of primary school and retention of rate debated. This study is an attempt to fill this gap by investigating the factors that influence of sociocultural practices on child participation in primary school education in view of the School Meals contribution of Bossaso town, Bari Region, Puntland. The literature review indicates that primary school participation in education determined by various factors including socioeconomic and cultural factors. According to a study in 1983, examined 115 children aged 12 to 13 years who enrolled in three classes in a poor rural area school. One class was served school breakfast with the other two classes serving as controls. The impact evaluation included school achievement, attendance, and weight gain. School achievement measured using tests that included arithmetic, spelling and reading. Children followed over two semesters. After the first semester, the treatment group showed improved school attendance and arithmetic scores compared to the control classes, but no difference in weight gain. After controlling for school attendance, academic improvement remained significant showing some evidence that reducing hunger during school hours could affect learning of arithmetic Powell and Grantham-McGregor (1983). This study will focus comparable system of Control groups from primary schools benefiting current school and non-target groups.

\subsection{Critique of the literature review.}

This study designed to provide additional information analyses and assessments on school on the effects of School Feeding imitative on enrolment, retention and reduction of the dropout's pupils.

Generally, there are strong believe and confident that School Feeding Programme has positive effect increased enrolment and minimize dropouts in addition to other advantages such cognitive development and prevention of malnutrition and short-term hunger. This study will emphasizes to extent to which School Feeding realize on that assumption in Puntland. As result of the widespread food insecurity originated from conflicts and Natural disasters, WFP and education sector of Somalia reached agreement to introduce School Feeding programme with purpose of two main purposes of nutrition protection and increased enrolment through attraction of food incentive at the school time.

FENPS (Formal Education Network for Private Schools), a humanitarian organisation established in 2003, launched an education project to provide close to 5,000 school-aged children between five and 15 years in Mogadishu, the capital of Somalia, with free-of-charge quality education and nutrition through a school feeding project. The project aimed to ensure the fundamental right of people in crises to quality and relevant education, with special attention given to the safety and wellbeing of the children.

Through the project, children given nutrition lessons where they taught good eating habits and healthy practices. These lessons integrated into the school curricula. After the nutrition lessons, the children were provided with a nutritious meal that consisted of fruit soup (different fruits mixed and cooked together with water and some oil), cooked rice, milk for drinking, a banana and sometimes a cooked egg and/or meat, mango juice or porridge. In addition to the meal, children provided with a ration of supplementary food to take home. FENPS followed WFP's Food Basket guidelines to design the rations. FENPS bought foods for this programme from the local meals in the markets.

However, there are number of studies who identified that School Meal has it's gaps which may hinder school feeding expected achievements in these in Compensatory reduction in food intake at other times 
include Food offered is not consumed, or provides too little of the missing nutrient, Low bioavailability, and Supplementation occurs too late

\subsection{Research Gap}

Research gap may in this study due to lack or shortage of other literature review or secondary data done by the researchers in Somali context and most of the reference narrated from other countries from Africa, such as Kenya, Malawi, Mali, and Southern Africa. Large part of the literature also conducted from Latin America and Asia, which may not be relevance to the Somali context, exist regarding most of the literature review documents are either old or irrelevant to the local context or conducted the neighbour countries.

Analyses gap may arise since no in-depth research was not done before by the schoolers except Government and funding agencies related to the implementation of the programme which indicate how school feeding improve enrolment and general performance of the pupils.

\subsection{Introduction}

This chapter emphases the research methodology of the study. It describes the research paradigm that is most suitable for carrying out this study. It also explains the research instruments used and how the data collected procedures, analyzed and interpretation.

\subsection{Research Design}

The study undergoes a case study design that carried out in Bossaso primary schools with both qualitative and quantitative methods. The design explores and evaluate in details the relationship between the variables (for this matter the relationship between independent variable, school feeding programme and dependent variable; pupilse participation in education - enrolment, attendance, class participation and dropout). Descriptive survey can also be used to investigate a population by collecting sample to analyse and discover occurrences.

\subsection{Population of Study}

This study conducted in Primary School in Bossaso district. The study targets population of study are teachers and the school principal for 16 primary schools in Bossaso district of Bari region. The total population of the study were 60 participants (45male and 15 Female) who selected randomly from the schoolteachers. Vice and Focal Point of the SFP.

\subsection{Methods of the data collection:}

The researcher carried out the research study for a period of about four months under the guidance of the university supervisors. Upon approval of the research proposal, the researcher first obtained research permit from the Puntland State University (PSU), which is Sponsoring University. Upon granted the permission to carry out the research study, the researcher reported to Bossaso district Education Officer (DEO) for further permission and then proceeded to the selected primary schools with a letter of introduction explaining the purpose of the study and the research permission.

The researcher visited the selected primary schools in the district and further obtained permission from the head teachers in order to access the respondents. The researcher personally administered the questionnaires to class teachers, and the head teachers for interview.

\subsection{Reliability Test}

Referring to Wellington (2000) Validity refer to the degree to which a method a test or a research tool actually measures what is supposed to measure while reliability entails the extent to which a test a method or a tool gives consistent results across a range of settings and if used by a range of researchers. In order to confirm validity and reliability of the research instruments for this study, piloting of the questionnaire were done and distributed to 10 questionnaires to the Bossaso Secondary School and incorporate the feedback to the questionnaire. 


\subsection{Sample Size and Sampling Procedure}

Large sample size statistically chosen for this study to minimize the probability of sample inaccuracy. Two schools used piloting study. According to the Kombo and Tromp (2006) observed that sample size of minimum $10 \%$ of the target population would be representative. Based on this premises, $80 \%$ of the 20 of the Bossaso Primary Public schools under school feeding program purposively selected of this research study.

The sampling technique has been applied to select 40 schools in which school 20 of them fall under school feeding program and 20 school used as control for comparison in Bossaso district. All 20 schools Head teachers, Vice and School feeding focal point teacher selected as purposively to participate the study because of the knowledge, administrative and experiences of the school feeding program. The control school were used only secondary data from the Ministry of Education.

The research study had sample size of 60 respondents, composed of 20 Head teachers and 40 teachers including vice and focal points of the school meals.

\subsection{Instrumentation}

A research is a device or tool used for gathering and collecting data with view of answering stated research questions Oso \& Onen (20009). Research instruments used were two questionnaires for head of school Teachers and teachers including vice principle, which utilized for data collection. Each questionnaire was divided in to two parts; part A based on respondents demographic information while part B composed of questions about the influence on school feeding in terms of retention rate, gender parity, enrolment rate and Academic performances in relation to school feeding program.

\subsubsection{The Questionnaire}

In this study, the questionnaire was the most preferred tool for collecting the data. This questionnaire carefully designed in a simple language that may not need any more clarification from the side of the researcher. Some open-ended questions constructed to give the respondents opportunities to reply more broadly.

The questionnaires will develop easy and clear this facilitated to get respondents as timely managed.

A questionnaire prepared and distributed to secure responses to certain questions. It is a systematic compilation of questions that are submitted to a sample of a population from which information discussed" MOE officials beforehand.

\section{Questionnaires designed to be:}

Simple and clear the questions phrased in such a way that they are direct and the respondents could read easily and answer the questions and this facilitated me to get more respondents and easier to interpret data.

Easily understandable in terms of their language and comprehensive in terms of content coverage.

It was so exciting for the children especially, and respondents likely to filled answers on time as needed.

Application and processing. Some questionnaires needed some analysis and independent thinking because the phrasing motivated learners to understand the study as being a tool to improve certain issues pertaining to the programme and its administration at school level

General and specific. Some of questions were generic and straightforward like asking their sex but some questionnaires were specific like classroom practice. So specific questionnaires will be very effective and could achieve the objective of the study.

\subsubsection{The interview}

The interview scheduled to conduct after completion of questionnaires for all school Head Teachers, Vices and Focal Point of the SFP. The questions constructed in a sequential order with those questions of general interest coming first. 


\section{Methods of Data Analysis}

After collecting the data, analyzing started by using different methods and programs for data analyzing and preparing statistical reports. In this, paper Ms. Excel program extensively used for all interpretations, tables and charts to show clearly how the target respondents collaborated with the researcher and how their responses varied in the questionnaire. The study focused on the following. How is the School Feeding effect on school enrolment rate? What is your views of the impact of school feeding on Academic performance of your school? What is the effect on school feeding on retention rate of your school? How School feeding effect gender parity of your school?

\section{1: Introduction}

This chapter deals with the research findings and discussion of the data presentation examination. It mainly reviews key issues from the theoretical and empirical literature, and compares similarities the dissimilarities findings systematically and possible relationships to fulfill the overall objectives of the research. The analysis was in line in accordance with the study objectives and variables of the study. The variables of study were the influences of School Feeding program on performance of Bossaso Public Primary. The analysis was presented in percentages, descriptive means and standard deviation and analysis of variance tables.

The study begun with response rate of the sample size, general information of the sample, and provides findings according to the following study objectives: To assess the effect of school feeding programme on enrolment rate Primary Schools of in Bossaso district. To investigate the effect of school feeding programme on public primary school pupilse academic performance in Bossaso District. To determine effect of school feeding programme on retention rate of the primary school in Bossaso District. To determine the effect of school feeding programme on gender parity of primary school pupils in Bossaso district.

\subsection{Response rate}

60 respondents were sampled in the study and the response rate was $100 \%$ since all of them responded. The respondents were composed of 45 of male and 15 female interviewed and reached according to the plan initially, which corresponding to $100 \%$. This corresponding to the response rate representation of the sample size and of the entire population.

\subsection{3: Demographic characteristics of respondents}

The below table indicate demographic representation of the respondents which were Head Teachers and Teachers of the target schools under School Feeding Program

Table 4.1:-Gender of the respondents

\begin{tabular}{|l|l|l|}
\hline Gender & Frequency & Percentage \% \\
\hline Male & 45 & 66.6 \\
\hline Female & 15 & 33.3 \\
\hline Total & 60 & 100 \\
\hline
\end{tabular}

According to the above table of out of 60 Interviews $66.6 \%$ were men and $33.4 \%$ were women from sample target population. This indicate that were significant gap between respondents in the gender point of view. The main reason canbe explained that Female Teachers are less compared their Male Teachers counterparts in Puntland. This has contributed to the cultural bias of the male counterparts to the female roles according to the traditional norms.

In the view of experiences and years of service of respondents from target sample population below table explains.

Table 4.2:-Period of Teaching services and occupational experiences of the respondents and interviews

\begin{tabular}{|l|l|l|}
\hline Years of Services & Frequencies & Percentage \\
\hline $1-5$ Years & 12 & $20 \%$ \\
\hline 6-10 Years & 24 & $40 \%$ \\
\hline $11-15$ Years & 15 & $25 \%$ \\
\hline Above 16 & 9 & $15 \%$ \\
\hline
\end{tabular}




\begin{tabular}{|l|l|l|}
\hline Total & 60 & $100 \%$ \\
\hline
\end{tabular}

As table 4.2 indicate the duration of teaching services to investigate teacher experience in school teaching and school feeding program practices. In terms of services, 20 percent serviced teaching work between 1-5 years while 40\% served 6-10 years and 25\% served as teachers for 11-15 years and more than $15 \%$ served as teaching professionals. This indicate that teaching is reliable source of employment and the sector accommodate higher proportion of the Puntland employee.

\subsubsection{Influence of School Feeding on Enrolment rate:}

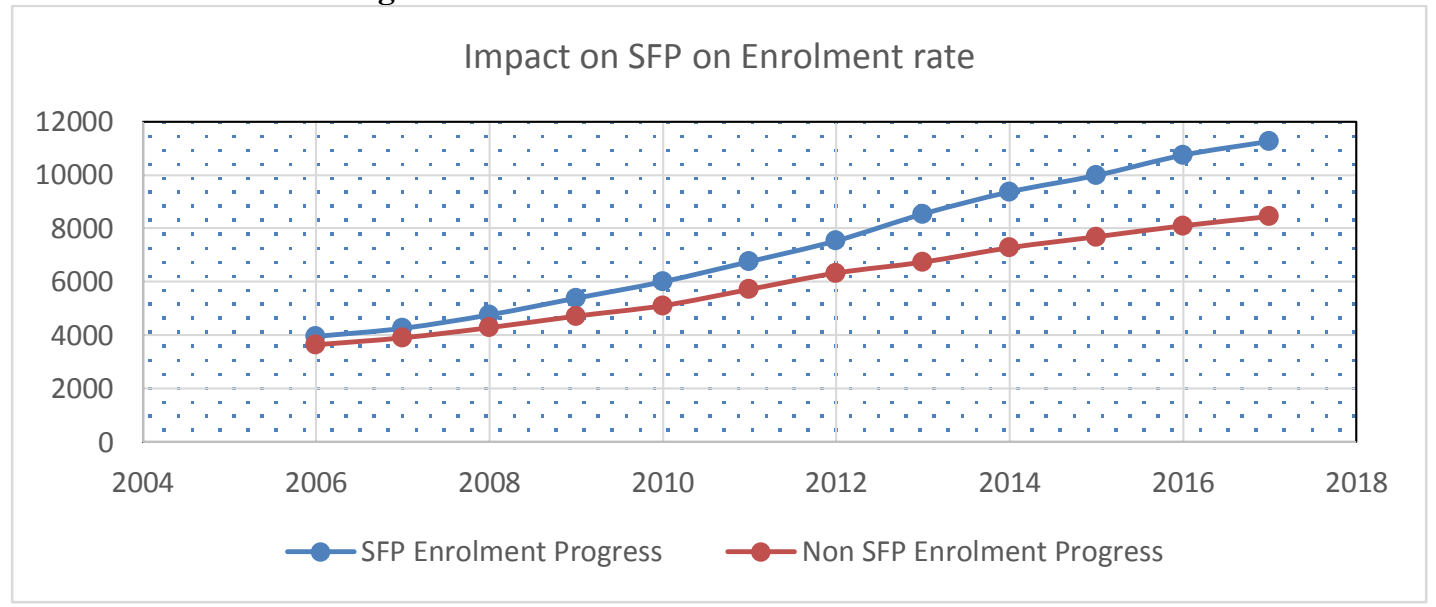

Fig 4.1:-Graph on School enrolment progress under WFP School Program

In the above graph of 4.1 it indicate that the enrolment rate of schools benefiting from school feeding program bigger in the first year of school meals introduction relatively by $8 \%$ of 207 . In addition, continue to improve from 2008 to 2010 where the enrolment rate of Feeding Program in Bossaso Primary Schools by increased by $12 \%$ to $13 \%$. In addition, enrolment rate maintained increasing steadily in 2012 to 2013 by 12-13\% comparatively. However, enrolment rate begun to decline from 2014 to 2015 by ten percent to down seven percent. According enrolment graph illustrated enrolment rate fluctuate from 2016-2017 by from eight to five percent and expected to maintain in the next years due to new increased primary schools.

Study found that over course of the school feeding program, the total enrolment rate achieved $110 \%$ compared to non-school feeding enrolment rate which increased by $88 \%$ during last twelve years since school feeding launched.

For Non-School Feeding Schools, the Graph (4.3) the data from Ministry Of Education indicate that enrolments increased in 2006 to 2009 increased from seven to ten percent flowed by remarkable reduction enrolment rate for year 2010 by eight percent. In addition, significant enrolment increase observed from 2011 to 2012 by twelve and eleven percent. However, Non-school Feeding Schools shown very significant reduction of enrolment rate in the year 2013 by $6 \%$ while enrolment rate 2014 slightly improved by 2015. According to the above graph, registration and new admission depicted continues decline in the last two years of 2016-2017 and reached the lowest enrolment rate by 6\% to 5\% currently.

Tabel 4.3:-Perception of Teachers and Head Teachers on the influence of School Feeding to the enrolment rate.

\begin{tabular}{|l|l|l|l|}
\hline Respondents & Frequency & Percentage & Remarks \\
\hline Strongly Agree & 35 & 58.4 & \\
\hline Agree & 17 & 28.3 & \\
\hline Undecided & 5 & 8.3 & \\
\hline Disagree & 3 & 5 & \\
\hline
\end{tabular}




\begin{tabular}{|l|l|l|l|}
\hline Total & 60 & 100 & \\
\hline
\end{tabular}

According above table (4.3) 58.4\% of the interviewed respondents strongly agreed and $17 \%$ shown Agreed that School Meals contribute positively influence enrolment rate of the Pupils in Bossaso Public Primary Schools. On the other hand 8, 2\% of the respondents expressed that they cannot decide whether there are relationships between School Meals and increased enrolment rate of the primary School children and feedback of the remaining 5\% responded that there is no relationship between School Meals and increased or decreased admission rate of the primary School Children in Bossaso district. This group of interviewers belief that community understanding the important of education as building better future for young generation are the main driving factor of the enhanced enrolment rate in Bossaso primary school who are benefiting school feeding program.

\subsubsection{Influence of School Feeding on Gender Equality:}

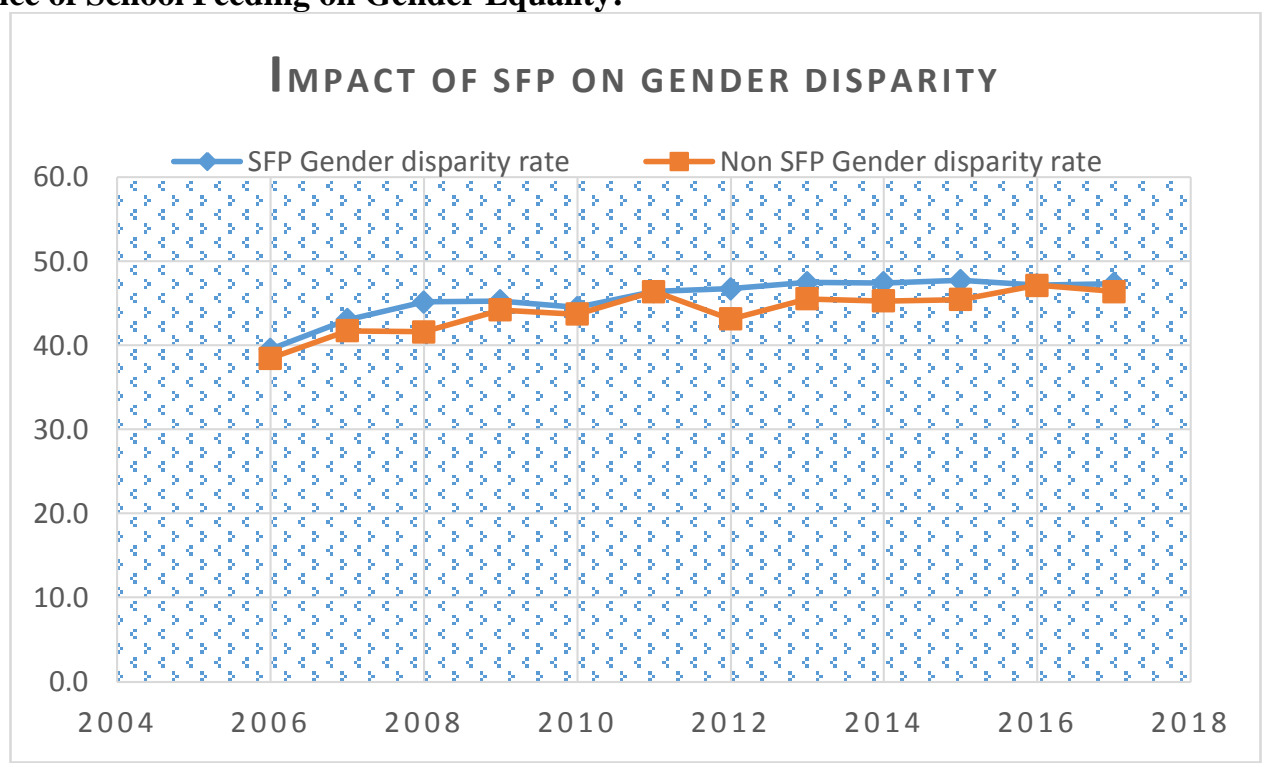

Fig 4.2:-Graph on Influence of School Feeding on gender equality

According to the above graph (4.2) Girls enrolment rate started in the beginning of the school feeding program in 2006 by $39.5 \%$ compared to their boys counterparts. The girl's enrolment rate increased by $43 \%$ in 2007. In addition, significant change recorded in 2008 to 2010 by $45.1 \%$ to $45.2 \%$ followed by slight reduction by $44.5 \%$ in 2010. The school Feeding enrolment rate in terms of gender equality continue to raise in small margins by 46 to $46.7 \%$ between 2011 t0 2012. However, girls enrolment improved from 2013 to 2015 by 47.4 to $47.7 \%$ and continue maintain improved enrolment from 2016 t0 2017 by small margins of 47.1 to 47.3. Despite the smaller margins per year girl's enrolment increase in WFP School Feeding Schools, it has shown significant changes from $39.5 \%$ to $47.3 \%$ from the beginning of the School introduction to Bossaso district of Bari region in 2006.

For Non School Feeding Schools, Girls enrolment has been improving compared to their male counterparts and data in 2006 shown that enrolment rate was $38.46 / \%$ and continue to increase with slight upward moving in 2007 to 2008 by 41.72 and $41.58 \%$ relatively. However, significant progress made in terms of gender equality of the Non-School Feeding Schools in Bossaso district and 2009 to 2011 girls enrolment rate increased from 43.2-46.4\% achieved with slight reduction 2012. However, Girls enrolment increased upward from 2013 to 2014 with same margins by 46.52 to $46.41 \%$ compared to the boys enrolments of the Public Primary Schools. Again, average performance sustained from 2015 to 2017 by 45.41 to $46.35 \%$.

Table 4.4:-Perception of Teachers and Head Teachers on the influence of School Feeding to the gender equality in terms of primary School enrolment in Bossaso district.

\begin{tabular}{|l|l|l|}
\hline Respondents & Frequency & Percentage \\
\hline
\end{tabular}




\begin{tabular}{|l|l|l|}
\hline Strongly Agree & 28 & 46.7 \\
\hline Agree & 14 & 23.3 \\
\hline Undecided & 10 & 16.7 \\
\hline Disagree & 8 & 13.3 \\
\hline Total & 60 & 100 \\
\hline
\end{tabular}

As above results indicated approximately, $46.7 \%$ of the teacher and Head teachers interviewed confirmed that they strong agree with positive impact of the school feeding in relation to the gender equality compared to the boys' enrolment rate. While $23.3 \%$ of the interview replied with Agreed which is also remarkable percentage. However, significant number of Interview answered that $16.7 \%$ that they were not decided and in contrast, 13.3 replied they disagree that there is relationship between school feeding and gender parity of the of the Bossaso public primary Schools.

\subsubsection{Influence of School Feeding on Retention rate:}

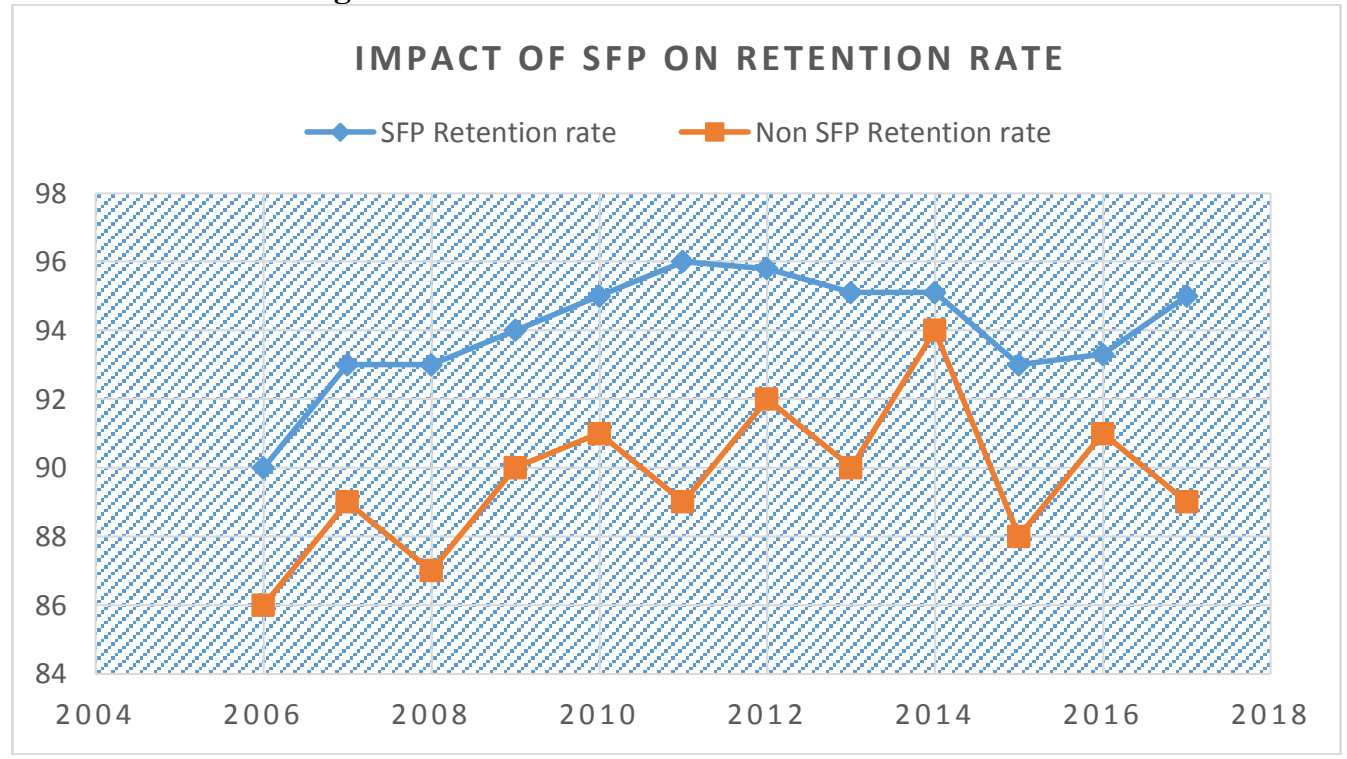

Fig 4.3:-Graph on Influence of School Feeding on Retention rate

Rendering to the Graph of (4.3) indicates retention rate of the School Feeding program during study period, shows steady progress $t$ in terms of the retention rate in relation to School meals. The Retention rate of the schools receiving meals started in 2006 by $90 \%$ and steadily made upward progress up to 2012 to achieve $96 \%$ in equivalent of four percent dropouts. However, Retention rate indicated slightly downword by $5 \%$ of dropouts in the next two years, and continue to maintain 7 percent of the dropout's rates until 2017. Retention rate of the School Feeding Schools achieved again by 95\% in 2017, according to the secondary data from Ministry of Education in Puntland. On the other hand, non-School feeding retention rates has been slow compared school feeding retention rates in Bossaso Public primary Schools. School pupils completing scholastic year from enrolment to final exams achieved retention rate from 89 to $94 \%$ during the last twelve years. This an indication that dropouts maintained from six to 11percent which an average of $8.5 \%$ compared to School Feeding programs which an average of six percent.

Overall, retention rate has been higher for School Feeding compared to those without feeding programs for 10 years out of 12 years, which can determine that school feeding program has a direct influence on dropout reduction measures and

Table 4.5:-Perception of Teachers and Head Teachers on the influence of School Feeding to the retention rate for primary School enrolment in Bossaso district.

\begin{tabular}{|l|l|l|}
\hline Respondents & Frequency & Percentage \\
\hline Strongly Agree & 30 & 50 \\
\hline Agree & 17 & 28.3 \\
\hline
\end{tabular}




\begin{tabular}{|l|l|l|}
\hline Undecided & 9 & 15 \\
\hline Disagree & 4 & 6.7 \\
\hline Total & 60 & 100 \\
\hline
\end{tabular}

The respondents in above table, asked if the School Feeding has any positive influence on retention rate of the primary school pupils in Bossaso district and significant number shown that they Strongly Agree by $50 \%$ while $28.5 \%$ of the respondents conformed that Agreed with the positive impact to the school feeding beneficiaries. Overall 78.5 supported that school feeding contributed students to finalize scholastic year through daily attendance to have meal with learning planed curriculum.

Among the respondents of Head teacher and Teachers there have been undecided of $9 \%$ on whether school feeding has any influence on dropout reduction or not and $4 \%$ who totally disagree that relation between school feeding and increased or sustained retention rate in Bossaso Public Primary Schools. The respondents believe that, there are other factors that may have strong influence on dropout reduction including increased awareness of the parents to the importance of education to the children as an important factor for future development.

\subsubsection{Influence of School Feeding on Academic Performance:}

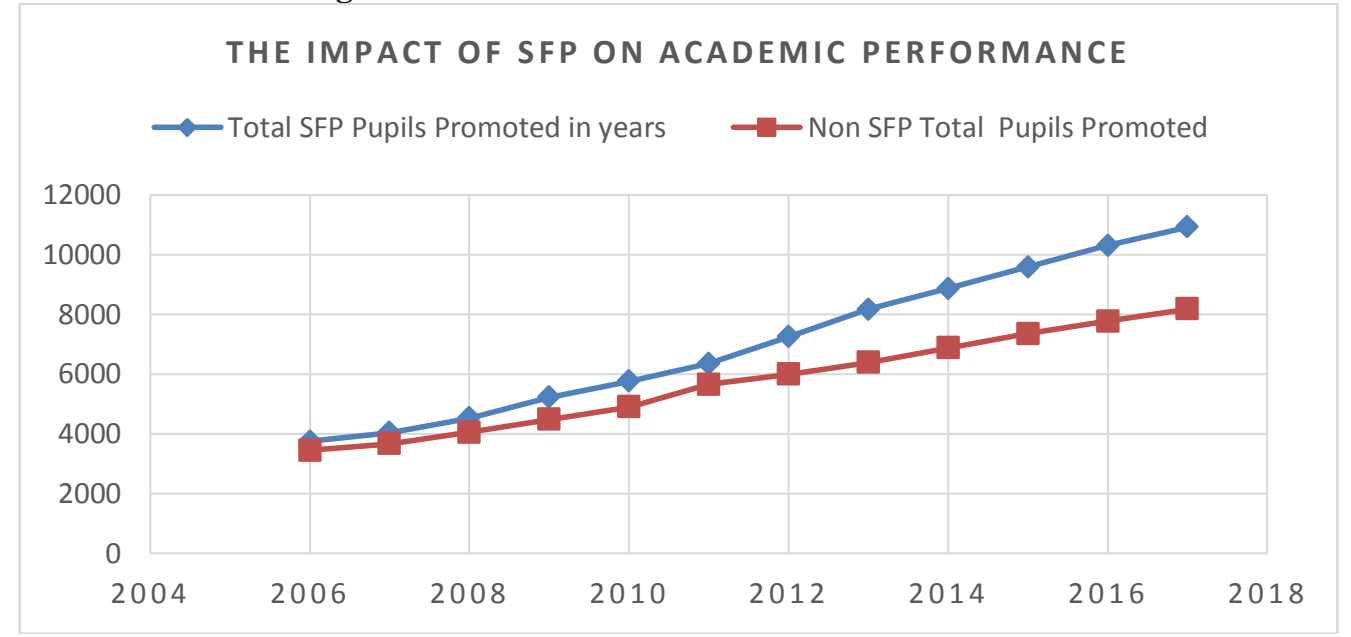

Fig 4.4:-Graph on Influence of School Feeding on Academic Performance

According to the graph (4.4), the Academic Performance of the Bossaso Public Primary Schools indicated that in relation to the School Feeding program point out that in 2006 to 2008 the promoted students were constant $95 \%$ to 95.2 percentage but steadily made progress with slight fluctuations between 2009 to 2010 by $97 \%$ and $96 \%$. The promotion rate dropped down to $94 \%$ in 2011 , which is the lowest rate, compared to the previous years. Again Academic Performance shown upward progress by $96.2 \%$ in 2012 followed by 2 years of decline by 95.2 to $94.7 \%$ which is small margin but significant due to higher number of the School Pupils under School Feeding program. However, Students performance again shown increased performance by 96\% to 97\% from 2015 to 2017 consecutively.

For Non-School Feeding Pupils the performance was obviously different from School Feeding program group in most years according MOE data and in 2006 t0 2010 the promoted student to next year were 94.8 to 96\%. Nevertheless, the period between 2011to 2014 the Non School Feeding Primary School maintained decline by $95.6 \%$ to the $94.6 \%$ consecutively. And in the last three years the Academic Performance increased significantly compared to the previous years by $95.7 \%$ to $96.8 \%$. Although other factors can influence the Academic Performance of the Primary school pupils. School feeding contributed significant impact according to the study findings. 
Table 4.6:-Perception of Teachers and Head Teachers on the influence of School Feeding to the Academic Performance for primary School enrolment in Bossaso district.

\begin{tabular}{|l|l|l|}
\hline Respondents & Frequency & Percentage \\
\hline Strongly Agree & 21 & 35 \\
\hline Agree & 14 & 23.3 \\
\hline Undecided & 7 & 11.7 \\
\hline Disagree & 18 & 30 \\
\hline Total & 60 & 100 \\
\hline
\end{tabular}

As displayed above table (4.6) on Head Teachers and Teachers respondents in terms of academic performance in relation to the School Feeding Programme for Bossaso Public primary Schools and results were $35 \%$ strongly agree that School Feeding has positive influence while 23.3 replied in favorable of Agree answers. This indicate that more than 58\% that School meals contributed pupils promotion to the next scholastic year. Remarkable percentage of $11.7 \%$ shown reluctant to decide whether School Meals any affect students promotion or academic performance of the target beneficiaries in Bossaso district of Bari region. However, large portion of the interviews confirmed their disagreements by $30 \%$ that School Meals contribute Academic performance of the Pupils of the Bossaso Primary Schools. These respondents suggested that there are other factors contributed such as quality of education, teacher's experiences and others.

\subsection{Introduction}

This research anticipated to discovery the influence of School Feeding to the Performance of Primary Schools in Bossaso district of Bari region in Puntland Sate of Somalia, in terms of enrolments, retention, gender equality and academic performance. The analysis of this research was carried out and results obtained to answer research questions and to come up with recommendations that are relevant to the findings.

\subsection{Major findings of study}

\subsubsection{Influence of School Feeding on Enrolment Rate}

The main findings of the study summarized according to the results of the research and it has confirmed that in general the School Feeding Schools increased by $110 \%$ compared to the Non School Feeding, which achieved enrolment rate of $88 \%$ during the last 12 years according to the MOE data. Head Teacher and Teachers perception on whether School Feeding contributed pupil's enrolment positively responded remarkably agreed strongly by $58 \%$ and small insignificant percentage replied that School Feeding has no direct relation with the gained enrolment rate during the period understudy.

\subsubsection{Influence of School Feeding on Gender Equality:}

The second objective of this study was to reveal the extents of the School Feeding influenced gender parity among the Pupils in the Public Primary Schools in Bossaso district. The study indicated that gender gap between boys and girls significantly decreased during the course of the school Feeding program for those benefited School Meals compared to the Non School Meal Schools in same district. The average proportion as percentage of girls in the SFP maintained $46 \%$ compared to Non SFP, which remained $44 \%$ during the last twelve years of School Meals Program in Bossaso district of Bari region. The study revealed that Non SFP Schools girl's enrolment rate were higher at the beginning of School Meal introduction compared to the program beneficiaries. However, Girls enrolment rate achieved great progress for 10 out of 12 years compared to the Non School Feeding performance, which clear signal on how School Feeding influence positively gender parity among the Primary School Pupils in Bossaso district of Bari region of Puntland Sate in Somalia.

The study discovered under Head Teachers and teachers responses that School Feeding improve girls enrolment rate compared to the Control School and thus contribute gender equality in Bossaso Primary Schools. The research found that $47 \%$ of the respondents strongly agreed, while the feedback of $23 \%$ shown agreement with School Feeding supports on reducing gender disparity amongst boys and girls in the elementary stage of the Schools in Bossaso district. This achievement on enhancing girl's enrolments and attendances 
In Pakistan, a program provides an income transfer in the form of one or two tins of oil toFamilies whose girls attend school for 20 days per month. In its pilot, phase the oil incentiveProgram demonstrated that it could make a significant contribution to full attendance. InParticipating schools enrollment improved by $76 \%$ compared to $14 \%$ in the province overall. Attendance increased from $73 \%$ to $95 \%$ among participants. The program also claims to putAdditional food into the hands of mothers and to serve as a contact between mothers andTeachers on distribution days (WFP, 1995; 1996).

The girls received additional food incentives as Take Home Ration for female pupils enrolled under School Feeding beneficiaries. Girls received $5 \mathrm{Kg}$ of cooking Oil at end of each months, which adds additional value for school feeding for female students. This likely to be contributed to reduce gender disparity between boys and girls. However, Take Home ration incentive were not distributed last two years,

\subsubsection{Influence of School Feeding Program on Retention rate}

Globally School Feeding enhance retention rate and decreases dropout for pupils from poor households during scholastic year from registration stage to closure of the scholastic year. This study determined that the retention rate of the School Feeding target beneficiaries performed well than Non School Feeding pupils by an average of 94\% compared to the Control group who maintained $92 \%$ of retention. The research established that according data from Ministry during last 12 years 9 out of 12 years Schools under Feeding programs maintained higher retention rate than schools are not beneficiating school meals.

The study found that Head Teachers and Teachers supported that School Feeding has a direct impact on Pupils retention at school during last twelve years and 50\% of the respondents strongly agree while $28 \%$ also shown that they agree the impact of school feeding to the Bossaso primary Schools. According additional comments from Teachers confirmed that school feeding reduce dropouts during drought where pastoralist move with their families and livestock seeking better pasture and water. This happens predominantly Bossaso rural areas where income sources mainly depend on livestock However, significant percentage of $15 \%$ of the target population could not decide whether school-feeding meals supported dropout reduction due to presence of the variables that can upheld student attendance throughout Scholastic year. The study established that $7 \%$ of the respondents replied that School Feeding has no direct or indirect impact on pupil's retention and dropouts of the Bossaso Public Primary Schools. The study concluded that School Feeding stabilized enrolment of girls and boys at high risk of dropping out from target primary schools and Improved retention rate. According Ministry of Education data from Bossaso Primary School total dropout from Non School Feeding Schools during from 2006 to 2017 reached 5469 student who could not accomplish scholastic years while School Feeding Program target schools total dropout were 5017 Primary School Pupils in Bossaso district.

\subsubsection{Influence of School Feeding on Academic Performance:-}

The study established that school feeding improved Academic Performance of the target School Feeding program comparing to non-School Feeding and according to the Ministry of Education statically data shown that the percentage of failure or non-promoted students under School Feeding World Program by 2.3\% while failures or non-promoters for Non-School Feeding pupils were 5\% during last twelve years. The academic performance has a direct link with the pupil's retention, attendance and influence positively according to the research findings in Bossaso Public Primary School.

The influence of School Feeding to Academic Performance or to the achievements of the results at the end of the scholastic years during the study period. The responses of the Head teachers and Teachers were also in line with the findings and 58\% supported that the School Feeding contribute good academic performance or higher achievements compared to non-school Feeding or Control Schools. However, significant percentage of $30 \%$ of the respondents suggested that school feeding has no direct relation with the academic achievements and there are other reasonable factors that pupils performances in terms of promotion from one scholastic to another, which is main achievements. The study recognized that during study period 8 out of 12 years School Feeding Program beneficiaries achieved higher promotion rate or success to the next scholastic year compared to the non-School Feeding primary Schools of Bossaso Public Primary Schools. 


\subsection{Conclusion of the study}

The conclusions arising from the findings of the research that required finding out the influence of School Feeding in Bossaso Public Primary school summarized here.

School Feeding increased enrolment rate for school with School meals through attraction of wet food distribution at school which can contributes on overall education development of the Primary Schools in Bossaso and Puntland generally. This has been apparently indicated through comparison between School Meals and Non Schools Meals. These gains from school feeding further improve attendance, and reduction of hunger period during school time.

Relationship between School Feeding and increased enrolment has further confirmed by the respondents and researchers where food availability at school kept children to attend the classes regularly throughout scholastic year in addition to food security improvement for pupils from poor households including Internally Displaced people. Therefore, government and donor agencies has to establish long strategy for school implementation covering entire primary Schools in Bossaso district and Puntland. Considering the importance of enrolment on education sector, school feeding can be one of the tools to reduce dropouts. Contribution of Supplementary food items to increase palatability and deliciousness of the school meals for effectiveness enhancing of enrolment rate and for additional nutritional values.

The study was also focused the contribution of the school feeding to the gender parity amongst school pupils in Bossaso Public Primary Schools, in terms of enrolments in the last 12 years. The research discovered that school feeding consistently contributed reduction of gender disparity in the target schools under school Feeding Program comparatively to non- school feeding schools. According to the statistical findings from Ministry of education data gender equality has been higher for School under School feeding Program compared to Non-school feeding Schools for 11 out of 12 years which an indication the significant impacts of this program. Take Home Ration (THR) for girls demonstrated encouraging improvement where 5 to $6 \mathrm{Kg}$ of Vegetable Oil distributed to female Pupils on monthly bases. The family appreciated both education and food contribution from girls because of the class attendances of more 24 days each month. If girls receive both wet feeding meals and Take Home Ration from the primary schools in Bossaso district, this will lead to greater gender equality among the Primary schools as suggested by Head teachers and Teachers interviewed. The greater girl's enrolment to the primary schools can be also be attained through continuous mobilization participating by all stakeholders including Ministry of Education, Parental association and NGos to break the barriers from cultural background of the Somali Society.

The findings of this study indicated that school feeding influenced positively retention rate of the school feeding beneficiaries compared to the non-school feeding beneficiaries. Because of the high attendance to participate school meals at the breakfast and lunch time, this improved the number of school pupils completing academic years. The data from Ministry of education from Bossaso district primary Schools are encouraging in terms of retention rates and school beneficiaries shown higher retention compared to non-school feeding beneficiaries by $94 \%$ and $92 \%$. School feeding can be one of the several tools that can minimized primary school dropouts, including girls which shown higher dropouts compare male pupils due to cultural, social, and economic factors, notably in Puntland where higher dropouts remained the main challenges of the primary schools, because of political instability, poverty and lack education incentives from government including limited employment for school graduates and poor quality of primary and secondary education

The conclusion from the study obtained the relationship between School Feeding and academic performance of the Bossaso Public primary Schools proved that school meals contributed significant and 11 out of 12 year's school feeding pupils performed higher than non-school feeding pupils did. Although the percentage difference is not so large but, academic performance was one of the key variable that research has investigated. And each of these variable were shown it's positive contribution to the overall achievements of the educational goals in Bossaso primary schools and that can be signpost if the school feeding program extend to the non-school feeding program, then overall academic performance of the Bossaso Public Primary Schools can results positive achievements. However, effective school feeding program could be achieved through collective efforts and contribution of more resources from 
stakeholders including distribution of complementary and supplementary food items to make schools more nutritious and palatable to reach effective to the desired goals of the school feeding.

In short, the research discovered that the School Feeding Program had the greatest impact on Academic Performance where Schools under School Feeding Program, a total percentage of the Primary pupils passed to the next Scholastic year were of $98 \%$ an average under period of study. In contrast, Primary School Pupils under Non School Feeding Program total percentage promoted to the next Scholastic year were 95\%. This indicates that Primary School Pupils benefiting from Schools Feeding Program only $2 \%$ failed to pass the national examination of the Ministry Of education. While an average, 5\% of the Non School Feeding Program failed to pass to the next Scholastic year during the period of study according to the data from Puntland Ministry of Education. This can be an indication that School feeding can be an appropriate incentive for Primary School Pupils learning motivation and Government and other education sector stakeholders to contribute more for implementation of this program to fill the gap. The other variable which shown good impact was enrolment rate although not constant

\section{Recommendation:-}

The results reached this study have number of suggestions and recommendations to the school feeding stakeholders including those involved education policy education makers and donor agencies notably governments, parental associations or Community Education Committees ( CEC ), Head teachers and active contributors to the school feeding program. Based on the study findings and interviews from the stakeholders of the School Feeding Program, this study made the following recommendations.

Expansion of the school feeding to the other non-school feeding public primary schools in Bossaso district and other districts so as to achievements gained by School Feeding programs beneficiaries including but not limited higher retention, enrolments, gender equality and Academic performances.

The quality of the School Meals must be improved through distribution of locally preferable traditional foodstuff, so that pupil's food acceptance can be improved to attain nutritional and educational objectives.

Re-introduce Take Home Ration for girls in Bossaso primary Schools to reduce further Gender disparity, which is in line with Millennium Development Goals and Sustainable Development Goals for education.

This is in line with the research findings where school Head of Teachers and Teachers recommended incentive Take Home ration for important gender equality among school pupils in Bossaso district. Governments and Humanitarian agencies involved school-feeding Program for Puntland has to distribute supplementary food items to increase palatability of the food distribute at the school. Currently, supplementary food items such as vegetable, meat Sugar, and spices and associate cost such as fire fuel, staff and water comes through community contribution, which sometimes cannot afford particularly during drought seasons.

\section{Suggestions for the further study.}

Further study and research to be conducted to investigate how School Feeding Programme contribute to the education notably Primary Education in Somalia to have a greater knowledge on the impact of SFP in Somalia. The study should cover how effectiveness of the SFP cost to the target groups. It is also advised to investigate food preferences of the school Pupils in different regions of Somalia to be funded the right food and right choice.

\section{Refrences:-}

1. Ahmed, A. U. ( (2004).). "Food for education Programmmes With Locally Produced Food: Effects on Farmers and Consumers in Sub-Saharan Africa", . Washington, DC.: International Food Policy Research Institute. http://ebrary.ifpri.org/cdm/ref/collection/p15738coll2/id/126379

2. Ahmed, A. U. (2004). IMPACT OF FEEDING CHILDREN IN SCHOOL: The United Nations University. https://www.researchgate.net/profile/Akhter_Ahmed/publication/253422918_Impact_of_feeding_children_in_s chool_evidence_from_Bangladesh/links/0c96052abf50faaee0000000/Impact-of-feeding-children-in-schoolevidence-from-Bangladesh.pdf 
3. al, B. e. (2011). The impact of school health Programme EVIDENCE FROM BANGLADESH: . Catherine Grant, Institute of Developmmental Studies. https://www.academia.edu/3768702/The_impact_of_school_feeding_programme

4. Aldelman, G. \&. (2009). How Conflict-Induced Shocks Shape Human Capital Formation. University of Oxford.

5. https://www.researchgate.net/publication/228554313_Childhood_Interrupted_How_Conflict-

Induced_Shocks_Shape_Human_Capital_Formation

6. Douben. (2006). INFLUENCE OF SCHOOL FEEDING PROGRAMME ON PUPILS. Nairobi University.

7. http://erepository.uonbi.ac.ke/bitstream/handle

8. Durkheim, E. ((1951). Treatise on the Socail roatsof Social Deviation.

9. https://www.encyclopedia.com/social-sciences-and-law/sociology-and-social-reform/sociology-general-termsand-concepts/social-problems

10. Eaton, J. B. (2000). College Student Retention - Defining Student Retention, A Profile of Successful Institutions and Students, Theories of Student Departure.

11. http://www.se.edu/dept/native-american-center/files/2012/04/College-Student-Retention-Defining-StudentRetention-A-Profile-of-Successful-Institutions.pdf

12. Garmezy. (1993). A Review of Literature of Resilience and Implications for Further Educational Research. San Diego: Claremont Graduate University \& San Diego State University.

13. https://go.sdsu.edu/education/doc/files/01370-ResiliencyLiteratureReview\%28SDSU\%29.pdf

14. Omago. (1990). INFLUENCE OF SCHOOL FEEDING PROGRAM ON ACADEMIC. Nairobi

15. https://cees.uonbi.ac.ke/sites/default/files/cees/dan\%20project_0.pdf

16. UNESCO). (2010). UNICEF Report. UNICEF.

17. https://www.unicef.org/publications/index_58840.htm

18. Wachs'. (2000). Review of biological, social, and psychological factors .

19. Walberg. ( (1981) ). Walberg's theory of educational productivity. Institute for Applied Psychometrics,llc 01$07-$

20. http://www.iapsych.com/acmcewok/Walberg\%27stheoryofeducationalproductivity.html

21. Z. W. ( (2004). Constructivism in Education,An overview of contributions to the literature and to the JPACTe annotated bibliography .

22. http://www.jpacte.org/uploads/9/0/0/6/9006355/2007-1-richardson.pdf

\section{Appendedices}

My name is Issa Omar Musa, a student at Jomo Kenyatta University of Agriculture and Technology, who is offering a Masters 'degree of science in Development Studies. Carrying out a research study on the, INFLUENCE OF SCHOOL FEEDING PROGRAMME ON PERFORMANCE of PUBLIC PRIMARY SCHOOLS in BOSSASO DISTRICT BARI REGION. I am privileged to have you as my respondent and the information given to me is purely academic and will be treated with confidentiality.

Part One: General Information.

Please tick ( ) in the bracket in front of the most appropriate response and where explanation is required, use the space provided.

Questionnaire Part 1: Teachers Perception on the effect of the School Feeding on Pupils enrolment

School Name--------------- No of Teachers-------- M-------- F----------- Date -----------

Position of the Teacher Please Tick.

1. A. Head Teacher (------) B. Deputy (------) C. Teacher (------)

2. A- Sex. Male (----) B. Female (-----)

3. Years of teaching service. 1-5 Years (----). 6-10 Years (----) 11-15 Years (-----)And above 16 years (------)

How School Feeding effect on school enrolment rate?

\begin{tabular}{|l|l|l|l|l|l|}
\hline Response & 5 & 4 & 3 & 2 & 1 \\
\hline Strongly Agree & & & & & \\
\hline Agree & & & & & \\
\hline Disagree & & & & & \\
\hline Strongly disagree & & & & & \\
\hline Undecided & & & & \\
\hline
\end{tabular}


How do you rate school feeding contribute to gender parity?

\begin{tabular}{|l|l|l|l|l|l|}
\hline Response & 5 & 4 & 3 & 2 & 1 \\
\hline $\begin{array}{l}\text { Strongly } \\
\text { Agree }\end{array}$ & & & & & \\
\hline Agree & & & & & \\
\hline Disagree & & & & & \\
\hline $\begin{array}{l}\text { Strongly } \\
\text { disagree }\end{array}$ & & & & & \\
\hline Undecided & & & & & \\
\hline
\end{tabular}

How do you rate School Feeding effect on school Retention rate?

\begin{tabular}{|l|l|l|l|l|l|}
\hline Response & 5 & 4 & 3 & 2 & 1 \\
\hline Strongly Agree & & & & & \\
\hline Agree & & & & & \\
\hline Disagree & & & & & \\
\hline $\begin{array}{l}\text { Strongly } \\
\text { disagree }\end{array}$ & & & & & \\
\hline Undecided & & & & & \\
\hline
\end{tabular}

How do you rate School Feeding effect on school Academic Performance?

\begin{tabular}{|l|l|l|l|l|l|}
\hline Response & 5 & 4 & 3 & 2 & 1 \\
\hline Strongly Agree & & & & & \\
\hline Agree & & & & & \\
\hline $\begin{array}{l}\text { Strongly } \\
\text { disagree }\end{array}$ & & & & & \\
\hline Agree & & & & & \\
\hline Not decided & & & & & \\
\hline
\end{tabular}

